Donald Huddle is professor emeritus of economics at Rice University, Houston, Texas. David Simcox, formerly executive director of the Center for Immigration Studies, is a Ph.D. candidate at the University of Kentucky. This article is reprinted with permission from Population and Environment, a Journal of Interdisciplinary Studies, Vol. 16, No. 1, September 1994.

\title{
The Impact of Immigration on the Social Security System
}

By Donald Huddle and David Simcox

[Synopsis: In 1992, the estimated deficit of the entire Social Security System attributable to the foreign born was $\$ 2.7$ billion (i.e., payments the foreign born paid to and received from the system). Also in 1992, there was an estimated surplus of $\$ 19.0$ billion for the native born population. During the 1993-2002 decade, the $\$ 2.7$ billion annual deficit attributable to the current stock of immigrants is projected to grow by about one percent annually in present value terms, reaching $\$ 2.98$ billion yearly in 2002. The ten-year deficit for the 1993-2002 decade would amount to nearly \$30.0 billion in 1993 dollars. In policy terms, the addition of large numbers of less skilled foreign workers to the labor force (which will occur if there is no change in immigration law or enforcement policy) in the hope of bolstering the solvency of the Social Security System would in fact have the opposite effect.]

\section{Introduction}

This study examines the entire foreign-born population and the legal immigrant, illegal alien and amnesty alien sub-populations separately in order to calculate the current Social Security balance (a deficit) between contributions paid and benefits received. The ultimate costs to the system of post-1970 immigration, which can only be fully assessed after individuals reach retirement a variable number of years into the future, are also estimated.

The method of the study involves: 1) calculating from the 1990 census the total Social Security benefits received by the foreign-born population in 1989, then adjusting the data for the year 1992; and 2) determining the total payments of the foreign-born into the Social Security System for 1992.

The difference between contributions paid and benefits received determines whether the participation of the foreign-born in the Social Security System increased or diminished the total public assistance and displacement cost deficit of $\$ 42.5$ billion which was found in a separate analysis of 1992 alien public assistance, transfer payments, and services use (Huddle, 1993).

\section{Findings: Current Contributions Paid and Benefits Received by the}

\section{Foreign-Born Population}

I. 1992 Social Security Benefits
Received by the Foreign Born

Data from a one-percent survey (Foreign Born, 1993) of the U.S. population 15 years old and more in the 1990 census shows that:

- 2.08 million foreign-born persons age 62 and over received payments for old age, survivors or disability insurance totaling $\$ 12,554$ billion, an average of $\$ 6027$ annually per recipient.

- 242,800 foreign-born persons ages 15-61 received benefits totaling \$993.7 million, an average of \$4092 per person.

- total benefit payments in 1989 to the foreign born 15 years of age or over totalled $\$ 13,548$ billion, adjusted by the (1985-1989) $5.8 \%$ annual rise in the Consumer Price Index (CPI) to an estimated \$16.044 billion in 1992 (U.S. Census, 1993, p. 357).

- $65 \%$ of the foreign born age 62 or greater receive Social Security benefits, compared to $78.5 \%$ of the comparable native-born population. Average payments to the foreign born were slightly higher (by $0.4 \%$ ) than those to the native born.

\section{1992 Contributions of the Foreign \\ Born to Social Security}

All the nation's covered workers and employers contributed a total of $\$ 382.0$ billion in payroll taxes to the Social Security System in 1992 (U.S. Census, 1993, p. 316).

The entire foreign-born population in 1992 was estimated at 21.16 million. The respective shares of the total contribution are estimated for each of the following immigrant sub-populations:

A) all legal immigrants, including those naturalized - a population estimated at 16.24 million in 1992;

B) all illegal immigrants, numbering 4.8 million in 1992;

C) all amnesty, or "legalized," aliens totalling 2.52 million in 1992.

A. The Legal Immigrants' Contribution. Legal immigrants comprise the largest subpopulation of the foreign born. They are also the highest earning group 
and the most likely to disclose their full earnings and comply with tax rules, as a smaller proportion works in the underground economy compared to the illegal and amnestied aliens.

\section{"While legal immigrants' contributions are low compared to the national average, they must be further adjusted downward..."}

The study of the impact of immigrants on Los Angeles County (Impact, 1992) found that the legal immigrant population contributed $\$ 929$ per capita to Social Security. Note that this is a per capita figure, not a figure per worker actually covered. Applying the national coverage percentage $(53.0 \%$ of the population in 1992), 8.72 million legal immigrants would have been covered by Social Security and have contributed a total of $\$ 15.093$ billion in 1992 . Their per capita annual contribution counting both employer and employee shares of the $\$ 15.3 \%$ payroll tax would have been $\$ 1731$. That annual contribution implies an average taxable annual wage of $\$ 11,314$. The per capita annual contribution of all covered workers in the nation, in contrast, is \$2961, implying an annual average taxable earning of $\$ 19,335$.

While legal immigrants' contributions are low compared to the national average, they must be further adjusted downward for the following considerations:

- Downward adjustment of estimated contributions: The contributions that would have been paid by the working unskilled native born displaced or whose wages were depressed by legal immigrants are an offset to immigrant contributions. Every 100 low-skill legal immigrants in the workplace in 1992 are thought to displace 15.5 low-skill U.S. workers. (Huddle, 1993) and/or depress the wages of the native born by a similar amount (Altonji \& Card, 1991). Accordingly, the total contribution is reduced by $15.5 \%$.

Moreover, the Los Angeles study incorrectly assumes that the worker pays the entire payroll tax of $15.3 \%$ because the employer lowers the worker's real wage to cover his contribution. But various studies have shown that less than half the payroll tax is shifted to the worker (Ehrenburg and Smith, 1991, pp 74-75 and Note 1). To estimate conservatively, it is assumed here that fully half of the payroll tax is shifted to the worker, making his effective contribution $11.45 \%$ of earnings. The required adjustment further reduces the subpopulation's total effective contribution to Social Security by 18.8 percent (Impact, 1993).

These two adjustments reduce the contribution of the legal immigrant subpopulation by $34.3 \%$ to $\$ 9.91$ billion.
B. Amnesty Aliens' Contribution. The Los Angeles County Study found that amnestied aliens contributed $\$ 874$ per capita to the Social Security fund. Imputing this contribution to 2.52 million amnestied aliens yields a gross 1992 contribution to Social Security of \$2.202 billion. An estimated 1.36 million amnesty aliens actually covered would pay per capita Social Security taxes of $\$ 1619$, implying an average individual taxable wage of $\$ 10,583$ per year $-54.7 \%$ of the national average taxable wage.

The same adjustment is applied to amnestied aliens' Social Security contributions as to those of legal immigrants. (The adjustment factor to compensate for displacement of U.S. workers rises from $15.5 \%$ to $20.0 \%$ because of the larger proportion of low-skill workers among the amnesty ranks and their greater displacing effect.) The downward adjustments for taxshifting, $18.8 \%$, is unchanged. After adjustment, the net tax payment of this group to Social Security would be $\$ 1.48$ billion.

C. Illegal Aliens' Contribution. According to the Los Angeles County Study, illegal aliens on average paid $\$ 485$ per capita into Social Security. The total for the nation's estimated 4.8 million illegals in 1992 would be $\$ 2.327$ billion. Adjustment factor for il-legals is the same as that for amnesty aliens, yielding a total contribution to the fund of $\$ 1.51$ billion.

If national coverage rates apply, 2.58 million illegal aliens would be covered by Social Security, contributing an annual average of $\$ 902$. The implied annual taxable wage of $\$ 5895$ is markedly lower $(44.3 \%)$ than that of the amnesty population, many of whose characteristics they share. The difference may be due to substantial non-compliance by illegal workers or their employers with payroll tax requirements. According to a review, of employment surveys by immigration researcher David North (1989), 44\% of illegal aliens had received some wage payments in cash, compared to $17 \%$ of legal aliens, suggesting nonpayment of payroll and other taxes.

Note that the imputed annual wage for the three populations represents only the portion of their wage and salary income subject to F.I.C.A. tax. Nonwage and salary income and unreported wage and salary income are not calculated.

\section{Balance of Benefits Paid to Immigrants and Contributions Paid by Immigrants to Social Security}

Total contributions of the foreign born to Social Security, after adjustment, were $\$ 13.34$ billion in 1992 ; Old Age, Survivor and Disability Benefits (OASDl) paid to foreign-born persons were $\$ 16.04$ billion. Thus, the estimated deficit of the entire Social Security System attributable to the foreign born in 1992 was $\$ 2.7$ billion.

For comparison, total contributions of the native born to Social Security OASDl in 1992 were $\$ 292.0$ billion, 
and total benefits they received were $\$ 273.0$ billion. The surplus for the native born was thus $\$ 19.0$ billion.

During the 1993-2002 decade, the $\$ 2.7$ billion annual deficit attributable to the current stock of immigrants is projected to grow by about one percent annually in present value terms, reaching $\$ 2.98$ billion yearly by 2002. The cumulative ten-year deficit would amount to nearly $\$ 30.0$ billion in 1993 dollars.

\section{Higher Returns to}

\section{Low-Income Contributors}

The relative weakness of aliens' Social Security contribution record is an indication of the significantly greater proportion of low earners in the foreign-born population than among the native born. All immigrants in 1992 contributed only $5.1 \%$ of total Social Security contributions, but they constituted $8.4 \%$ of the population. Per capita gross payroll taxes of covered immigrant workers, before adjustment for displacement, tax shifting, or earned income tax credit grants, were $\$ 1712$. The comparable figure for native-born workers was \$2448. The lower-thanaverage earnings and contributions of the current stock of immigrants explains in part why current and future influxes of low-income workers are likely to drain the Social Security System rather than "save" it, as some (Bartley, 1993) would contend.

The progressivity of Social Security benefits is an important factor here. "Replacement rates," the percentage of average working income to be received after retirement, are set by law as follows:

\begin{tabular}{lr} 
Earning Levels & Benefit Levels \\
$\begin{array}{l}\text { Low earners (43\% of national } \\
\text { average wage) }\end{array}$ & $58.3 \%$ \\
$\begin{array}{l}\text { Average earners (100\% of } \\
\quad \begin{array}{l}\text { average wage) } \\
\text { Maximum earner (max. taxable } \\
\quad \text { wage - \$51,300) }\end{array}\end{array}$ & $42.7 \%$ \\
\hline
\end{tabular}

Under this formula, the low earner in 1990 would have received $\$ 5.41$ yearly in retirement benefits for each one dollar of average annual contribution. The average earner would receive $\$ 3.96$ yearly for every dollar of average annual contribution. The maximum earner would receive benefits of only $\$ 2.22$ for every dollar in his yearly pay-in (U.S. House, 1991, p. 46).

\section{Earned Income Tax Credit Liabilities}

Low earning workers with children, and with less than $\$ 22,370$ earned income, are eligible for Earned Income Tax Credits that can offset or often exceed their contributions in payroll taxes. In 1992, a working family of two adults with two children with an earned income of $\$ 16,950$ received from the Treasury basic refundable tax and health insurance credits totaling $\$ 949$. The statistics in Table 1 are the earned income tax credits obtainable by the three immigrant subpopulations at the earnings levels revealed by their
Social Security contributions, assuming two children per working family.

VI Recovery of Benefits

through Taxation

The Social Security fund now earns $\$ 3$ billion to $\$ 6$ billion a year from income taxes on Social Security income of medium to high income Americans. The effective tax burden runs from $1.2 \%$ of Social Security income of beneficiaries with total annual incomes of $\$ 30,000$ to $15.0 \%$ of incomes of beneficiaries above $\$ 100,000$. Beneficiaries with total incomes of $\$ 25,000$ or less are not subject to tax of their Social Security benefits.

The addition of large numbers of foreign workers to the work force in the hope of enriching the Social Security System, as some have urged, would, in fact, be counterproductive. The additional payroll taxes would be modest and, in the case of families with children which earn less than $\$ 18,000$, would be largely offset by refundable earned income tax credits and higher revenue losses from displacement of native-born workers. While immigrants have more children who will become contributors than the native born, it cannot be assumed that the children will be higher earners than their parents. Current immigration policy alters the skill endowment of the labor force for this generation and the next two (Borjas, 1993).

At the same time, assuming (no change in immigration law or enforcement policy and thus) a continuation of large-scale, unselective immigration, the system would acquire a disproportionate liability for benefits for today's low earning immigrants in the second decade of the next century, at the same time as the current surplus in the fund will be running out.

\section{REFERENCES}

Altonji, Joseph \& Card, David (1991). The effects of immigration on the labor market outcomes of less-skilled natives. In John M. Abowed \& Richard B. Freeman (Eds.). Immigration, trade and labor market. Chicago: University of Chicago Press.

Bartley, Robert (June 6, 1993). "Firing Line" with host William Buckley and guest Virginia Abernethy, New York.

Borjas, George (February 1, 1993). Why control the borders? - An immigration debate. National Review.

Ehrenburg, Ronald \& Smith, Robert (1991). Modern labor economics: Theory and public policy. N.Y: Harper Collins.

Foreign Born and Native Born Social Security Recipiency: A One-Percent Sample of PUMS tapes from the 1990 Census. (July, 1993). Washington, D.C: Decision Demographics (unpublished data).

Huddle, D. (1993). The costs of immigration. Washington, D.C: Carrying Capacity Network.

Huddle, D. (Jan. 26,1994). Can we afford so many unskilled immigrants? New York Times, Edit. pg.

Impact of Undocumented Persons and Other Immigrants on Costs, Revenues and Service in Los Angeles 
County: A Report Prepared for the Los Angeles County Board of Supervisors (November 6, 1992).

North, David (1989). Aliens and the regular and D.C: irregular labor market. Washington,

TransCentury Foundation.

U.S.Census Bureau (1993). Statistical abstract of the United States - 1992.

Washington, D.C:

Government Printing Office.

U.S. House of Representatives.

Committee on Ways and

Means (May, 1991). 1991 green

book: Overview of

entitlement programs. WMCP

102-9. Washington,

D.C: Government Printing Office
TABLE 1 Social Security Contributions and Earned Income Tax Credit (EITC) Entitlements of Three Immigrant Sub-Populations (Soc. Sec. contributions based on $11.48 \%$ of earnings)

\begin{tabular}{|c|c|c|c|}
\hline & $\begin{array}{l}\text { Legal } \\
\text { Immigrants }\end{array}$ & $\begin{array}{l}\text { Amnesty } \\
\text { Aliens }\end{array}$ & $\begin{array}{l}\text { Illegal } \\
\text { Aliens }\end{array}$ \\
\hline $\begin{array}{l}\text { Average Social Security } \\
\text { Earnings } \\
\text { Social Security Contributions }\end{array}$ & $\begin{array}{r}\$ 11314 \\
\$ 1298 \\
\$ 1640\end{array}$ & $\begin{array}{r}\$ 10583 \\
\$ 1214 \\
\$ 1835\end{array}$ & $\begin{array}{r}\$ 5895 \\
\$ 677 \\
\$ 1437\end{array}$ \\
\hline
\end{tabular}

Basic Tax and Health

Insurance

Credit (EITC)

Source: U.S. Internal Revenue Service, Publication 596. 